\title{
SURGERY FOR JUVENILE OTOSCLEROSIS: A LITERATURE REVIEW
}

Contributions: A Study design/planning B Data collection/entry C Data analysis/statistics D Data interpretation E Preparation of manuscript F Literature analysis/search $\mathrm{G}$ Funds collection

\section{Henryk Skarzynski ${ }^{1 A D E F}$, Beata Dziendziel ${ }^{1 D E F}$, Joanna J. Rajchel ${ }^{1 D E F}$, Piotr Henryk Skarzynski ${ }^{1,2,3 D E}$}

\author{
${ }^{1}$ World Hearing Center, Institute of Physiology and Pathology of Hearing, Warsaw/ \\ Kajetany, Poland \\ ${ }^{2}$ Heart Failure and Cardiac Rehabilitation Department, Medical University of Warsaw, \\ Warsaw, Poland \\ ${ }^{3}$ Institute of Sensory Organs, Warsaw/Kajetany, Poland
}

Corresponding author: Piotr Henryk Skarżyński, PhD; ORCID: 0000-0002-4978-1915; E-mail: p.skarzynski@ifps.org.pl; Tel. +48 2235603 20; Address: Mokra 17 Street, 05-830 Nadarzyn, Poland

\begin{abstract}
Otosclerosis is a disease characterized by abnormal bony growth and remodeling around the otic capsule. Although adults make up the majority of patients, otosclerosis is also encountered in children. However, the literature on juvenile otosclerosis is still limited. The main therapeutic options for children with otosclerosis are hearing aids or stapes surgery. Despite many years of treating pediatric patients with stapes surgery, the issue of whether to perform the operation is still a subject of debate. To identify suitable literature on juvenile otosclerosis, a search was performed using the following databases: PubMed, Web of Science, and Medline, and based on the search criteria 19 articles were found suitable for the review. The current evidence indicates that stapes surgery for juvenile otosclerosis is a safe and effective procedure which leads to closure of the air-bone gap over both short and long terms. Complications of stapes surgery are extremely rare and in the majority of cases comprise transient vertigo. Age itself should not be a contraindication to stapes surgery for juvenile otosclerosis.
\end{abstract}

Key words: stapes surgery, otosclerosis, child, postoperative complications, hearing loss

\section{ESTAPEDOTOMÍA COMO MÉTODO DE TRATAMIENTO DE LA OTOESCLEROSIS INFANTIL - REVISIÓN BIBLIOGRÁFICA}

\section{Resumen}

La otoesclerosis es una enfermedad que se caracteriza por la formación de tejido óseo anormal alrededor del laberinto y la reconstrucción de sus componentes. Aunque los adultos constituyen la mayor parte de los pacientes operados por otoesclerosis, dicha enfermedad también afecta a niños. Sin embargo, las publicaciones científicas relativas a la otoesclerosis en niños son escasas. La forma de tratamiento más común de los niños con otoesclerosis es la aplicación de audífonos o bien tratamiento quirúrgico. Pese a que tenemos ya años de experiencia en el tratamiento de pacientes pediátricos mediante la cirugía del estribo, la decisión de realizar o posponer dicho procedimiento sigue despertando controversias. Para fines de la presente revisión, se realizó una búsqueda de publicaciones en las bases medicas de datos PubMed, Medline y Web of Science, y utilizando criterios de inclusión en el estudio se eligieron 19 trabajos. En base a los resultados analizados se puede concluir que la cirugía del estribo es un procedimiento seguro y eficaz que permite cerrar la reserva coclear tanto en observación a largo, como a corto plazo. Complicaciones tras estapedotomía son muy poco frecuentes y en la mayoría de los casos suponen trastornos temporales del equilibrio. La edad del paciente como tal no debe ser una contra-indicación para realizar la cirugía.

Palabras clave: cirugía del estribo, otoesclerosis, niño, complicaciones posoperatorias, hipoacusia

\section{СТАПЕДОТОМИЯ КАК МЕТОД ЛЕЧЕНИЯ ДЕТСКОГО ОТОСКЛЕРОЗА - ОБЗОР ЛИТЕРАТУРЫ}

\section{Резюме}

Отосклероз является болезнью, характеризующейся образованием патологической костной ткани вокруг лабиринта и перестройкой его элементов. Хотя большинство пациентов, которым проводятся операции в связи с отосклерозом, - это взрослые, данная болезнь наблюдается также среди детей. Однако научные публикации касательно отосклероза среди детей и молодёжи всё ещё немногочислены. Наиболее распространённой формой терапии у детей с отосклерозом является использование слуховых аппаратов или хирургическое лечение. Несмотря на многолетний опыт в лечении педиатрических пациентов с помощью хирургии стремени решение о проведении или отсрочке операции продолжает вызывать споры. Поиск литературы для обзора вёлся с использованием баз PubMed, Medline и Web of Science, и, таким образом, на основании критериев, включающих в исследование, было выделено 19 работ. На основании проанализированных результатов можно констатировать, что хирургия 
стремени является безопасной и эффективной процедурой, позволяющей закрыть резерв улитки как при длительном, так и при кратковременном наблюдении. Осложнения после стапедотомии очень редки и в большинстве случаев касаются временных нарушений равновесия. Возраст пациента сам по себе не должен быть противопоказанием для проведения операции.

Ключевые слова: хирургия стремени, отосклероз, ребёнок, послеоперационные осложнения, потеря слуха

\title{
STAPEDOTOMIA JAKO METODA LECZENIA OTOSKLEROZY DZIECIĘCEJ - PRZEGLĄD PIŚMIENNICTWA
}

\begin{abstract}
Streszczenie
Otoskleroza jest chorobą charakteryzująca się tworzeniem nieprawidłowej tkanki kostnej wokoło błędnika i przebudową jego elementów. Chociaż osoby dorosłe stanowią większość pacjentów operowanych z powodu otosklerozy, choroba ta występuje również wśród dzieci. Jednakże, publikacje naukowe dotyczące otosklerozy wśród dzieci i młodzieży są nadal nieliczne. Najpowszechniejszą formą terapii dzieci z otosklerozą jest zastosowanie aparatów słuchowych lub leczenie chirurgiczne. Pomimo długoletniego doświadczenia w leczeniu pacjentów pediatrycznych za pomoca chirurgii strzemiączka, decyzja o wykonaniu lub odroczeniu operacji nadal wzbudza kontrowersje. Wyszukiwanie piśmiennictwa do przeglądu przeprowadzono przy użyciu baz PubMed, Medline i Web of Science i na podstawie kryteriów włączających do badania uzyskano 19 prac. Na podstawie przeanalizowanych wyników można stwierdzić, że chirurgia strzemiączka jest bezpieczną i efektywną procedurą pozwalającą na zamknięcie rezerwy słuchowej zarówno w długo- jak i krótkoterminowej obserwacji. Komplikacje po stapedotomii są bardzo rzadkie i większości przypadków dotyczą przejściowych zaburzeń równowagi. Wiek pacjenta sam w sobie nie powinien stanowić przeciwskazania do przeprowadzenia operacji.
\end{abstract}

Słowa klucze: chirurgia strzemiączka, otoskleroza, dziecko, komplikacje pooperacyjne, niedosłuch

\section{Introduction}

Otosclerosis is a disease characterized by abnormal bony growth and remodeling around the otic capsule (1) which progressively leads to conductive hearing loss. If untreated, otosclerotic foci may expand into the inner ear, destroying hair cells and resulting in both sensorineural and mixed hearing loss (2). Currently, the most effective treatment option for patients with otosclerosis is stapedotomy. It is a common otosurgical procedure that consists of making a small fenestra in the footplate and removing the stapes superstructure (3). Many factors are considered significant predictors of postoperative outcomes, including preoperative air-bone gap (ABG), the structures involved in the otosclerotic process, and the patient's sex, age, and laterality of hearing loss (4).

Although adults make up the majority of patients, otosclerosis is also encountered in children. Juvenile otosclerosis is a frequent cause of conductive hearing loss, along with otitis media and aural atresia (5). However, the literature concerning juvenile otosclerosis is still limited (6).

The main therapeutic options for children with otosclerosis are hearing aids or stapes surgery. Despite many years of treating pediatric patients with stapes surgery, the issue of whether to perform the operation is still a subject of debate. One of the most frequently cited authors in the field, John W. House, began a paper in the early 80s (7) with the strong statement: "Stapedectomy on a child? Never! But we believe that there are indications". In the past, researchers delayed the surgical treatment of otosclerosis due to the child's age, recommending use of a hearing aid until they were $8-10$ years old $(8-10)$. The reasoning was that the child should be mature enough a) to understand the procedure, and $b$ ) to be subjected to local anesthesia, which was used for the majority of patients at the end of the 20th century (11). However, recently it was claimed that earlier operations are worth considering when the child is suffering severe hearing loss and/or will not tolerate hearing aids (12).
In 2016, a meta-analysis on surgical success rates in congenital stapes fixation and juvenile otosclerosis was published, providing valuable information on pre- and postoperative ABGs (13). However, the cited review provided no information on broader aspects of surgery for juvenile otosclerosis in children or on developments that have happened over the last 50 years since the first report presumed to have been published on this topic by Hajek (14). In addition, the literature search was limited to articles published in English.

The aim of the current review was to synthetize knowledge derived from the literature on stapes surgery for juvenile otosclerosis, providing information on patient characteristics, diagnostic evaluation, use of preoperative imaging techniques, as well as the course of surgery, the results, and complications.

\section{Material and methods}

To identify suitable literature, a search was performed using the PubMed, Web of Science, and Medline databases. Using the keywords "stapes surgery", "child", "juvenile", and "otosclerosis", 188 articles were found on PubMed, 31 on Web of Science, and 46 on Medline. As the literature on the topic is scanty and one of the objectives was to analyze the developments that have occurred in the treatment of juvenile otosclerosis, we did not limit the timeframe of our search. The inclusion criteria were articles written in Polish, German, or English relating to stapes surgery in children.

The records were screened by title and abstract, analyzing full texts if there was any doubt concerning the suitability of the work to be included in the final review. After exclusion of articles - referring mainly to stapes surgery in adults (52 articles), metaanalysis, reviews, or case studies (10 articles), topics outside the scope of the current review ( 87 articles), etiology other than juvenile otosclerosis (such as congenital abnormalities, osteogenesis imperfecta, tympanosclerosis; 27 articles), or language other than 
Polish, German, or English (29 articles) - 60 articles were considered suitable for the current review. Finally, after excluding duplicates and articles not of interest to the review (e.g. not describing the results of the stapes surgery), 19 articles were found suitable for detailed study.

\section{Results}

\section{Patient characteristics}

Although the audiometric results of surgeries performed in various cases of the ossicular chain immobilization are usually reported separately, there is a trend towards the cumulative reporting of patient characteristics. Thus, it is hard to establish the basic data of age and sex of children who have undergone stapes surgery due to juvenile otosclerosis. Based on our estimates, over 400 cases of stapes surgery for juvenile otosclerosis have been described in the articles we reviewed. The age of the operated children ranged from 5 to 21 years $(9,15,16)$. Additionally, the mean age of the operated children changed significantly from 18 to 19 years in earlier studies (17) to about 11-13 years in more recent reports $(1,5,18)$. In most studies, the authors described the characteristics as a whole, without breaking the results down into individual age groups.

In the majority of studies, girls outnumbered boys by three or four times. Interestingly, the findings of studies which took into account the prevalence of otosclerosis in particular age groups reported that female otosclerosis occurred mainly in adolescents, whereas in younger cases (under 7 years) it was the males who outnumbered the females. A male predominance in younger children might relate to different genders having different lifestyles (11). The onset of hearing loss ranged from 5 years $(19,20)$ to 12 years, with a mean duration of 5 years before admission to the audiology clinic (16).

Patients with juvenile otosclerosis had bilateral hearing loss in the majority of cases; however, unilateral operations were more frequently reported than bilateral. The proportion of stapes surgeries performed in children, compared to the total number of all such operations performed in a given center, ranged from under $1 \%$ (17) to about $19 \%$ (21) in more recent studies. However, such information was often not provided directly by the authors and it is unsure if the large difference may result from changes in criteria connected with the development of surgical techniques, or the actual reflection of the research material at individual centers.

\section{Diagnostic evaluation}

Differential diagnosis of reported hearing loss is an important part of the preoperative evaluation (7). Already during the interview with a patient and their parents, much valuable information can be obtained. First of all, the diagnosis of otitis media should be excluded, confirming lack of such an episode over at least the last year $(5,11,20,22)$. In addition, children with congenital ossicular abnormalities usually have a negative family history of otosclerosis and they have no progression of hearing loss with time $(7,19,20)$. Patients with congenital abnormalities usually report earlier onset of hearing loss (9). Congenital malformations are also likely to have unilateral hearing loss, whereas juvenile otosclerosis usually appears bilaterally (7).

Skarżyński and Porowski (2) reported that advanced otosclerosis in children should be suspected in cases of concomitant tinnitus, deterioration of bone conduction, and/ or mixed hearing loss found on the audiogram. Such symptoms indicate an advanced and quickly progressing disease process and should be taken into account as factors accelerating the decision about stapes surgery. Unfortunately, only several authors described the accompanying factors of those children with juvenile otosclerosis admitted due to hearing loss. Lescanne et al. (23) reported 3 cases of preoperative tinnitus and 1 case of preoperative dizziness. Similar findings were reported by Denoyelle et al. (24), who noted the existence before stapes surgery of tinnitus in 3 patients, dizziness in 1 patient, and vertigo in 1 patient. No information was given on postoperative results.

The physical examination can also be a valuable source of information in making a preoperative assessment. One specific feature of patients with juvenile otosclerosis can be a bright pink hue of the promontory (a positive Schwartze's sign). In a differential diagnosis, it is worth noting that children with osteogenesis imperfecta frequently show a blue discoloration of the sclera (9). According to Neilan et al. (5), a contraindication to stapedotomy is intact tympanic membrane reflexes, which can indicate a third window of the inner ear (e.g. an enlarged vestibular aqueduct or semicircular canal dehiscence) in case of conductive hearing loss.

In one of the earliest reports on juvenile otosclerosis, House et al. (7) stated that a normal or reduced height tympanogram in case of conductive hearing loss is indicative of ossicular chain fixation (probably stapedial). Conversely, the authors indicated that discontinuity of the ossicular chain or a congenital cholesteatoma can be suspected if there is a high peak audiogram in a unilateral hearing loss case.

Pure-tone audiometry is considered the gold standard in assessing preoperative hearing levels. A basic criterion for qualifying a child for stapes surgery is obtaining consistent and reliable audiograms obtained at least twice before surgery $(2,22,25)$.

Although speech audiometry was considered an important part of the diagnosis in earlier studies (7), only several authors reported pre- and postoperative speech audiometry results.

Although the physical and audiometric examinations are a source of valuable information, a clinical diagnosis of juvenile otosclerosis or congenital malformation is only possible on the basis of the surgical picture and histopathological examination (20). Histopathology for juvenile otosclerosis is rare, and in the majority of evaluated studies the clinical diagnosis was made perioperatively based on the typical otosclerotic focus in the microscopic evaluation $(1,5,9,21,23,24)$.

Another valuable source of information enabling the differential diagnosis of juvenile otosclerosis is a computed 
tomography (CT) scan $(21,24)$. Such a tool enables observation of the status of the ossicles, the course of the facial nerve, and inner ear morphology (5). Inner ear deformities are generally considered a contraindication for stapes surgery (22). A CT scan can be particularly useful in diagnosing male patients with X-linked stapes gusher syndrome, who should not be considered as candidates for stapes surgery due to the high probability of postoperative sensorineural hearing loss.

Murphy \& Wallis (22) and Lippy et al. (11) conducted a CT scan only in children with mixed hearing loss. Similarly, Skarżyński \& Porowski (2) used this imaging method only in children suspected of congenital malformations of the middle or inner ear. In the study of Lescanne et al. (23), a CT scan was helpful in the preoperative evaluation of patients with juvenile otosclerosis; however the authors underlined its rather low sensitivity. The evidence of otosclerosis (poorly calcified foci near the fissula ante fenestram) was found in 4 out of 6 children. Denoyelle et al. (24), similarly to Welling et al. (15), Neilan et al. (5), and An \& Lee (21), conducted a preoperative CT scan in all evaluated children. Interestingly, Neilan et al. (5) underlined that most ossicular abberations did not show on CT but were identified intraoperatively. No information about using a CT scan preoperatively was reported in the most recent and only prospective study on primary pediatric stapedotomy by Vincent et al. (1).

\section{Surgery for juvenile otosclerosis}

The most common otosurgical procedure used in children with juvenile otosclerosis is stapedotomy. House et al. (1980) reported using a transmeatal approach in cases of firm suspicion of juvenile otosclerosis; however, in uncertain cases they advocated using a postaurical approach due to possible incus or malleus problems or unsuspected congenital cholesteatoma. The majority of authors reported using a transcanal access in case of juvenile otosclerosis $(1,2,7,9,16,21,22,25,26)$. In the 80 s, the most common reported type of anesthesia was local; however, current articles mainly describe general anesthesia in children.

There is a diversity of prostheses types used by different authors, starting from no prosthesis (27) to wire loop prosthesis $(7,17)$, stainless steel piston prosthesis $(11,16,22)$, platinum piston (9), gold piston (19), and the most commonly used Teflon prosthesis $(1,2,16,17,20,21,24,25)$. In a study by Welling et al. (15), no significant differences were obtained between patients with different types of prostheses, grafts, or age at operation. An apt summary of the encountered differences was set out by Carlson et al. (26), who stated that "There was a substantial variety of artificial prostheses used, reflecting the 20 year span of surgery and variations in surgeon preference". There was also a variety of grafts used during a surgery, including fascia $(7,9,15,24)$, vein $(1,11)$, blood or perichondrium $(9,15,22)$, fat $(22)$, fibrous tissue and blood (19), no graft (15), or "others" in over $20 \%$ of all procedures performed (9).

In the study of House et al. (7), 10 of 24 surgeries required drilling due to a solid footplate, with one case leading to total hearing loss even though the same technique was used in all cases. Drilling was also used by Namysłowski et al. (25) in 6 cases due to the presence of extensive otosclerotic changes, but no cases of hearing loss were noted. In a study of Millman et al. (16), no drilling was used and curettage was performed to remove bony overhangs or growths. De la Cruz et al. (9) reported using various techniques such as electric drill, needle hook, laser, or others. The authors outline the development of surgical techniques, comparing the total stapedectomy with wire prostheses (in the past) to small fenestra stapedotomy with platinum piston prostheses using a laser (in later years), which can be particularly useful during revision surgery. However, in the majority of studies the laser technique has not been frequently employed. Bachor et al. (19) used a carbon dioxide laser in only 2 cases. In the study of Denoyelle et al. (24), the stapes superstucture was removed and followed by either a small fenestra technique with a drill or laser or a partial removal of the footplate covered by fascia. Similarly, a laser was used in only 2 ears, whereas the drill was chosen in 22 ears. In a study of Neilan et al. (5), only 3 patients underwent a laser stapedetomy. The most extensive report on surgical procedure was provided by An \& Lee (21), who did not report using a laser. However, in the most recent report of Vincent et al. (1), all procedures were performed using a KTP laser or carbon dioxide laser. To summarize the variety of techniques used, it is worth recalling that Lescanne et al. (23) pointed out that the results of stapes surgery are much more influenced by the experience of the otosurgeon than by the choice of using either a laser or drill.

\section{Postoperative results of stapes surgery}

In the majority of studies, criteria set by the Committee on Hearing and Equilibrium were used to report the results of surgery. However, probably due to the retrospective nature of most studies, differences have been introduced. For example, in the study of de la Cruz et al. (9), hearing thresholds for $3 \mathrm{kHz}$ were not tested, so the $4 \mathrm{kHz}$ threshold was substituted in the average. In the study by Neilan et al (5), instead of using $3 \mathrm{kHz}$, the mean of 2 and $4 \mathrm{kHz}$ was used. Vincent et al. (1) in all cases used $4 \mathrm{kHz}$ thresholds instead of $3 \mathrm{kHz}$ when averaging the pre- and postoperative results. It is worth noting that pure-tone bone conduction thresholds generally tend to decrease after stapes surgery, being a reversal of the Carhart's notch. This is the reason for the commonly found recommendation of calculating the postoperative ABG using postoperative, not preoperative, bone-conduction thresholds (as was done in earlier studies), which should minimize underestimating the true size of the gap. Readers interested in the metaanalysis of juvenile otosclerosis results and their comparison with congenital ossicular chain abnormalities are invited to refer to the work of Asik et al. (13); in this review, results obtained by different authors in the individual studies are collectively presented.

Generally, surgery is considered successful if the ABG is closed to within $10 \mathrm{~dB}$; such a criterion was also chosen in the metaanalysis of Asik (13). Classification of postoperative hearing thresholds also follows similar lines. In the study of Namysłowski et al. (25), the results were divided into three categories: very good (ABG closed to within $10 \mathrm{~dB}$ ), good (ABG 10-20 dB), and disappointing (ABG $>30 \mathrm{~dB}$ ). Denoyelle et al. (24) and An \& Lee (21) classified 
their results into very good $(A B G<10 \mathrm{~dB})$, good (ABG 10$20 \mathrm{~dB}$ ), acceptable (ABG 20-30 dB), and bad (ABG >30 $\mathrm{dB}$ ). The authors of the cited works chose different periods for short- and long-term observation, ranging from about 2 to 6 months for short-term and at least 1 year for long-term evaluation.

In the study of Meurman (1975), stapes surgery was found to be an effective way of improving hearing ability in the short and long term. However, no data were provided on particular PTA upon pre- and postoperative evaluation. In the report of House et al. (7), the hearing bone-conduction thresholds were reported to be within $10 \mathrm{~dB} H \mathrm{HL}$ of preoperative levels in $91.7 \%$ of primary stapedectomies (22 of 24 procedures). Descriptions of the pre- and postoperative PTAs were also not provided. In a study of Murphy \& Wallis (22), 55\% obtained an ABG within $10 \mathrm{~dB}$ and the remaining within $20 \mathrm{~dB}$, with a mean hearing improvement of $17.6 \mathrm{~dB}$. Millman et al. (16) reported a hearing improvement of $58 \%(\mathrm{ABG}<10 \mathrm{~dB}$ ), 32\% (ABG $11-20 \mathrm{~dB}$ ), and $10 \%$ (ABG $>20 \mathrm{~dB}$ ) in the short-term observation (2-3 months), and $50 \%, 40 \%$, and $10 \%$ in the long-term follow up (17-23 years). However, the authors stated that there were no significant differences at different follow-ups, which indicated that stable hearing thresholds were maintained in the examined children. Additionally, no relationship was found between the postoperative ABG and age at surgery, family history, noise exposure, or the duration of the hearing loss. In the long-term observation, patients with obliterative and biscuit-type otosclerosis (analyzed together) had a lower chance of restoring the $\mathrm{ABG}$ to within $10 \mathrm{~dB}$ compared to those with separate stapes defects.

The results of Vick et al. (20) showed that 3 children had their ABG within $10 \mathrm{~dB}, 1$ child within $21-30 \mathrm{~dB}$, and 1 child with a perioperative gusher had an $A B G$ worse than $30 \mathrm{~dB}$. Namysłowski et al. (25) reported an ABG within $10 \mathrm{~dB}$ in 10 operated ears, within $20 \mathrm{~dB}$ in 5 operated ears, and worse than $20 \mathrm{~dB}$ in 1 operated ear. In the study of Skarżyński \& Porowski (2), as many as $97.7 \%$ of the children had their ABG within $10 \mathrm{~dB}$, and the remaining children had their ABG not lower than $20 \mathrm{~dB}$. Denoyelle et al. (24) obtained very good results in 4 children with juvenile otosclerosis and a good result in 1 child, which also persisted in the long term ( 1 remaining child was lost to follow-up). The results of Carlson et al. (26) revealed that $88 \%$ children with juvenile otosclerosis experienced at least a $10 \mathrm{~dB}$ improvement after stapes surgery. Neilan et al. (5) reported $57.0 \%$ of children with an $A B G<10 \mathrm{~dB}$ and $85.6 \%$ of children with $A B G<20 \mathrm{~dB}$. The mean ABG in pediatric patients in a study by An \& Lee (21) changed from $M=32.8 ; S D=8.4$ to $M=8.7 ; S D=6$. This result was also maintained in long-term observation (a minimum of 18 months). Vincent et al. (1) obtained a significant change in the ABG from $M=25.5 ; S D=5.7$ to $M=$ $3 ; S D=5.3$, persisting in the long-term observation. De la Cruz et al. (9) pointed that, considering the postoperative ABGs, there was no difference between patients with preoperative mixed and conductive hearing loss.

In a study by Lippy et al. (11), no recurrent conductive hearing loss was noted in the long-term observation. However, there were three cases of bilateral juvenile otosclerosis in which an operation was done at childhood on one side and the other side was postponed until adulthood. Successful stapes surgery was performed in all the pediatric procedures, although one patient who underwent an operation in adulthood experienced a total loss of hearing thereafter. Robinson (1983) reported a recurrent conductive hearing loss in 5 evaluated patients.

If the primary stapes surgery will not bring about the desired results, there is the possibility of revision surgery, which can increase the overall success rate from $79 \%$ to $89 \%$ (9). However, it worth noting that some studies indicate an increased risk of cochlear loss after revision surgery, similar to those reported in the adult literature (15).

\section{Complications}

Based on the analyzed literature, it can be concluded that complications due to stapes surgery are limited to individual cases. In the study of House et al. (7) the hearing loss of one patient was improved after stapes surgery but returned to the preoperative level with time. Another patient suffered total sensorineural hearing loss after the vestibule was drilling into while reconstructing the oval window with a wire prosthesis. Millman et al. (16) observed no complications directly after stapes surgery; however, one patient experienced a sensorineural hearing loss of 10 to $20 \mathrm{~dB}$ and conductive hearing loss was noted in another patient 8 years after surgery. Upon revision surgery, a displaced prosthesis was demonstrated and corrected, which resulted in ABG closure. The same patient reported a fluctuating sensorineural hearing loss and imbalance 15 years later, which was caused by a fistula near the anterior oval window. After revision surgery with placement of a scarified piece of perichondrium over the oval window and replacement of the prosthesis, good hearing resulted and there was no disruption to balance.

In the study of Lippy et al. (11), otitis media and atelectatic eardrum were found in one patient, which necessitated a tympano-ossiculoplasty. No other complications were observed. De la Cruz et al. (9) reported transient vertigo in 5 patients and a persistent taste disturbance in one patient. Welling et al. (15) described profound sensorineural hearing loss in one child and in another patient worsened speech discrimination (from $100 \%$ to $62 \%$ ) after revision surgery. Perioperative gusher was noted in one child in the study by Vick at al. (20). Namysłowski et al. (25) and Skarżynski \& Porowski (2) found no serious complications, reporting postoperative transient vertigo in a minority of patients. In the study of Denoyelle et al. (24) the only complication was tinnitus in one girl. Carlson et al. (26) reported a hearing loss of $15 \mathrm{~dB}$ in one patient after surgery. Two children reported symptoms of labyrinthitis in the study of Neilan et al. (5); dizziness recovered but hearing loss was sustained. At long-term follow-up, An $\&$ Lee (21) found one case of sensorineural hearing loss of $21.25 \mathrm{~dB}$ compared to the preoperative period. Finally, in the most recent prospective study, Vincent et al. (1) reported bone conduction deterioration of $13 \mathrm{~dB}$ in one patient as the only complication.

To avoid postoperative complications, certain recommendations need to be followed, no matter whether it is a stapes 
or other ear-related surgery (23). Pediatric patients should avoid straining activities, such as heavy lifting, and be careful when around water. They should also avoid sniffing or wiping when both nostrils are obstructed. Both the child and their parents should be aware that any symptoms such as dizziness, vertigo, or sudden hearing loss must be reported to the surgeon as soon as possible.

\section{Discussion}

Although the literature on pediatric otosclerosis is limited, the current evidence indicates that stapes surgery for juvenile otoslecrosis is a safe and effective procedure for restoring the hearing ability in children - preventing the social and personal burden connected with hearing aids and the potential stigma of wearing them. In addition, an early operation inhibits the on-going pathological destruction of the otic capsule and stops the progression of existing hearing loss (16). House et al. (1980) stressed that the child's age, their overall perception of the illness, the level of hearing loss, and whether the hearing impairment was unilateral or bilateral should be taken into account when choosing between hearing aids and stapes surgery. The authors advocated postponing treatment until the child was at least 5 years of age and any problems with otitis media (with or without effusion) had subsided. To provide evidence of stable hearing thresholds, the young patient should be monitored at 6 month intervals. Surgical treatment is not advisable in unilateral cases. The authors considered that surgery could be performed at any time in the future, but Robinson (28) said that postponing surgery in young patients was not in their best interest. Earlier studies found that if stapes surgery on pediatric patients with otosclerosis was delayed until adulthood, there were more cases of diffuse otosclerosis, which calls for drilling out the footplate. Waiting until a child is 18 years old before an operation is performed may in some cases lead to a total loss of hearing (11).

Based on the current literature, there is no evidence-based reason indicating that there is a certain age before which a stapes surgery should not be performed. Although some authors have reported complications after stapes surgery, they do not seem to be connected with the patient's age (15). The frequently cited concerns of postoperative otitis media (7) or sensorineural hearing loss (9) are extremely rare. The authors of studies included in this review tend to agree that the results of stapes surgery in children with juvenile otosclerosis are at least as satisfactory as results obtained in adult patients $(2,7,17,24,28,29)$.

The slightly lower success rates obtained by different authors can be explained by the methods they used $(9,30)$. Many early studies $(7,25,28)$ computed the ABG shift based on preoperative bone conduction threshold and postoperative air conduction threshold, which can bias the results (16). The current standard method of calculating the ABG compares hearing thresholds from the same period of time.

\section{Conclusions}

Despite methodological differences, most studies indicate that stapes surgery for juvenile otosclerosis is a safe and effective procedure which enables the ABG to be closed over both the short and long term. The complications of stapes surgery are rare and in the majority of cases comprise transient vertigo. Age itself should not be a contraindication to stapes surgery for juvenile otosclerosis.

\section{References}

1. Vincent R, Wegner I, Vonck BMD, Bittermann AJ, Kamalski DMA, Grolman W. Primary stapedotomy in children with otosclerosis: a prospective study of 41 consecutive cases. Laryngoscope, 2016 Feb; 126: 442-6.

2. Skarżynski H, Porowski M. Stapedotomia jako metoda z wyboru w leczeniu otosklerozy młodzieńczej. Audiofonologia, 2006; 29: 101-4.

3. Lancer H, Manickavasagam J, Zaman A, Lancer J. Stapes surgery: a National Survey of British Otologists. Eur Arch Otorhinolaryngol, 2016; 273: 371-9.

4. Kishimoto M, Ueda H, Uchida Y, Sone M. Factors affecting postoperative outcome in otosclerosis patients: predictive role of audiological and clinical features. Auris Nasus Larynx, 2015; 42: 369-73.

5. Neilan RE, Zhang RW, Roland PS, Isaacson B, Lee KH, Walter Kutz J. Pediatric stapedectomy: does cause of fixation affect outcomes? Int J Pediatr Otorhinolaryngol, 2013; 77: 1099-102.

6. Yellon RF, Thottam PJ. When should stapes surgery be performed in children? Laryngoscope. 2015 Dec; 125: 2631-2.

7. House J, Sheehy J, Antunez J. Stapedectomy in children. Laryngoscope, 1980; 90: 1804-9.

8. Teunissen EB, Cremers WR. Classification of congenital middle ear anomalies. Report on 144 ears. Ann Otol Rhinol Laryngol, 1993; 102: 606-12.

9. De la Cruz A, Angeli S, Slattery WH. Stapedectomy in children. Otolaryngol Head Neck Surg, 1999; 120: 487-92.
10. Thomeer HGXM, Kunst HPM, Cremers CWRJ. Isolated congenital stapes ankylosis: surgical results in a consecutive series of 39 ears. Ann Otol Rhinol Laryngol, 2010; 119: 761-6.

11. Lippy WH, Burkey JM, Schuring AG, Rizer FM. Short- and long-term results of stapedectomy in children. Laryngoscope, 1998 Apr 1; 108: 569-72.

12. Vincent R, Wegner I, Kamalski DMA, Bittermann AJN, Grolman W. Congenital stapes ankylosis in children: surgical findings and results in 35 cases. Otol Neurotol, 2016 Apr; 37: $367-73$.

13. Asik B, Binar M, Serdar M, Satar B. A meta-analysis of surgical success rates in congenital stapes fixation and juvenile otosclerosis. Laryngoscope, 2016 Jan; 126: 191-8.

14. Hajek EF. Juvenile otosclerosis. J Laryngol Otol, 1961 Jul; 75: 621-39.

15. Welling DB, Merrell JA, Merz M, Dodson EE. Predictive factors in pediatric stapedectomy. Laryngoscope, 2003; 113: 1515-9.

16. Millman B, Giddings NA, Cole JM. Long-term follow-up of stapedectomy in children and adolescents. Otolaryngol Head Neck Surg, 1996 Jul; 115: 78-81.

17. Cole J. Surgery for otosclerosis in children. Laryngoscope, 1982; 92: 859-62.

18. Carlson ML, Van Abel KM, Pelosi S, et al. Outcomes comparing primary pediatric stapedectomy for congenital stapes footplate fixation and juvenile otosclerosis. Otol Neurotol, 2013; 34: $816-20$. 
19. Bachor E, Just T, Wright CG, Pau HW, Karmody CS. Fixation of the stapes footplate in children: a clinical and temporal bone histopathologic study. Otol Neurotol, 2005 Sep; 26: 866-73.

20. Vick U, Just T, Terpe H, Graumuller S, Pau HW. Stapes fixation in children. HNO, 2004 Dec; 52: 1076-82.

21. An YS, Lee K-S. The surgical results of stapes fixation in children. Int J Pediatr Otorhinolaryngol, 2014 Jan; 78: 55-9.

22. Murphy TP, Wallis DL. Stapedectomy in the pediatric patient. Laryngoscope, 1996; 106: 1415-8.

23. Lescanne E, Bakhos D, Metais JP, Robier A, Moriniere S. Otosclerosis in children and adolescents: a clinical and CT-scan survey with review of the literature. Int J Pediatr Otorhinolaryngol, 2008 Feb; 72: 147-52.

24. Denoyelle F, Daval M, Leboulanger N, et al. Stapedectomy in children: causes and surgical results in 35 cases. Arch Otolaryngol Head Neck Surg, 2010 Oct; 136: 1005-8.
25. Namysłowski G, Ścierski W, Trybalska G, Mrówka-Kata K, Orecka B, Gac B. Leczenie otosklerozy u dzieci. Pol Merkuriusz Lek, 2005; 19: 331-2.

26. Carlson ML, Driscoll CLW, Gifford RH, et al. Implications of minimizing trauma during conventional cochlear implantation. Otol Neurotol, 2011 Aug; 32: 962-8.

27. Meurman O. Otosclerosis in children. HNO, 1975; 23: 337-8.

28. Robinson M. Juvenile otosclerosis. A 20-year study. Ann Otol Rhinol Laryngol, 1983 Dec; 92: 561-5.

29. von Haacke NP. Juvenile stapedectomy. Clin Otolaryngol Allied Sci, 1985 Feb; 10: 9-13.

30. Becker SS, Dobratz EJ, Stowell N, Barker D, Park SS. Revision septoplasty: review of sources of persistent nasal obstruction. Am J Rhinol, 2008; 22: 440-4. 
